\title{
Instructional Management Strategy: A Multi-Sites Study on Science Teaching for Islamic School
}

\author{
Abdul Ghofur ${ }^{1}$, Nahdia Rupawanti BR ${ }^{2}$, Abdul Kholid Achmad ${ }^{3}$ \\ ${ }^{1}$ STKIP PGRI Lamongan \\ Email: ghofurkita@yahoo.com \\ ${ }^{2}$ Universitas Islam Lamongan \\ Email: nahd.raharjo@yahoo.co.id \\ ${ }^{3}$ Universitas Muhammadiyah Gresik \\ Email: abdkholidachmad@gmail.com
}

(Received: October-2017; Reviewed: November-2017; Accepted: December-2017; Published: December-2017)

(7) (9) (92017-EST Graduate Program Universitas Negeri Makassar. This is an article with open access under license CC BY-NC-4.0 (https://creativecommons.org/licenses/by-nc/4.0/ ).

\begin{abstract}
This paper describes how management strategies in science learning are done by teachers in Islamic schools. This is motivated by the ranking of Indonesia which 87 percent of the population of Muslims always occupy the lowest position for the ability of science literacy. This research was conducted for four months using descriptive qualitative design with data collection technique of interview, observation and documentation. The subjects of the study were six Islamic schools in Lamongan, East Java. The six Islamic schools were chosen by purposive sampling. The results showed that the learning activities of science more dominated by teachers, students heard more explanation than the practice in verifying the process of science. The majority of teachers use lecture, question and answer methods, and assignments, and occasionally apply discussion and demonstration methods. Science laboratories in schools have not been maximally used, some have limited tools and materials, some of which lack laboratory space and even two schools without a science laboratory. Assessment of student learning progress done through pretest, posttest, daily test, question and answer during lessons, UTS and UAS. Teacher's strategy in managing student learning motivation by using animated video as apperception, integrating science materials with Islamic religious values.
\end{abstract}

Keywords: Instructional management strategy; science teaching

\section{INTRODUCTION}

Indonesia with a population of $87 \%$ of Muslims is experiencing Islamic awakening almost in all areas of life. Whether in the field of Islamic economics, veil, Qur'an literacy civil Islam, Islamic politics, Islamic law, Islamic art, Islamic lifestyle, (Rudnyckyj, 2009; SmithHefner, 2007; Gade, 1999; Hefner, 2000; Baswedan, 2004; Effendy, 1994; Heryanto, 2015; Jones, 2010), and many other fields.
Nevertheless, amid the euphoria of the Islamic awakening, there is one thing that is forgotten, that is science literacy. The results of recent studies conducted both nationally and internationally have always placed the literacy skills of Indonesian students at the bottom. National outcomes are known through the results of the National Examination (UN) conducted annually, while the results of the international evaluation are conducted by the Program for International Student Assessment 
(PISA) and by Trends in International Mathematics and Science Study (TIMSS). Even PISA evaluation results conducted from 2003 to 2015 always put Indonesia in a country with low science ability. In 2003 the literacy ability of Indonesian students' science was in the order of 38 out of 40 countries, then in 2006, Indonesia was on the order of 50 out of 57 countries. In 2009 the rank of science literacy of Indonesian students in 66 of 67 countries. In 2012, Indonesia's science literacy skills are ranked 64 out of 65 countries, and last year 2015 Indonesia is also ranked at the bottom of the list of 69 out of 76 countries (OECD, 2005, OECD, 2007; OECD, 2010; OECD, 2012; OECD, 2015). The same is also shown from the results of the TIMSS survey in 2015 that placed the literacy ability of Indonesian students science ranked 45 th out of 48 countries (Rahmawati, 2016).

The low literacy skills of Indonesian students who predominantly Muslim over the years illustrate the not optimal learning process at the unit level of education. When the learning process of science less than the maximum and tend to be boring, it certainly affects the perceptions and interests of students to science lessons themselves. This is based on several studies that show that science is a boring and unattractive subject. subject, Consequently, most students are less interested in learning science (Gok \& Silay, 2008; Liliasari, 2009). Though interest in a lesson is a very important factor in supporting the success of the learning process. According to Susanto (2013), in the world of education in school, interest plays an important role in learning, because this interest is a motivational force that causes a person to focus on a person, a thing, or a particular activity. Thus, if students have lost interest in learning science, it will significantly affect the motivation and response of students in following the learning activities of science conducted by teachers.

During this time, based on various studies of science learning tend to be taught monotonically. Learning strategies delivered by teachers were more tutorial and less practice. It is also expressed by Mahyudin (2007) that students only study science as a product, memorize theoretical and legal concepts to study science only at the low level of the cognitive domain. When the process of learning science is just a process of moving material from book to student, of course the activity feels boring. Technically, this is also described by Wisudawati and Sulistyowati (2014) that students who study science have not been able to use the scientific knowledge they gain to face real-life challenges. Student learning environment in the form of learning strategies created by teachers becomes an important factor to optimize students' ability in learning science lessons and using the concept of science in understanding the environment. The concept of science for most students is a difficult concept, because students rarely get an understanding of science lessons for their daily lives. For example, there is a concept of science in cooking activities involving heat energy (Physics), then mixing the spices produce a certain flavor and aroma (Chemistry). For example, the explanation of water is a liquid that can dissolve (Chemistry), and is a source of life (Biology) and many other examples. When teachers are able to bring the concept of science in understanding the environment in accordance with everyday life will make students more easily understand it.

Attempts to make students interested and interested in following every learning process of science will be constructive in improving learning outcomes optimally. So the strategy of teachers in managing science learning will determine the purpose. This is as the opinion of Milan (2007) that the level of success of learning is determined by the conditions developed during the learning. When teachers are able to find a suitable strategy in the management of learning based on the concept and the nature of science learning, will certainly be able to build the learning atmosphere that is expected, both by teachers, students, and other learning environments. According Sanjaya (2009) management of learning is an activity to control the learning activities based on the concept and principles of learning to achieve the goals set. Management of learning begins with the determination of strategy and planning, process, and assessment.

Based on these studies, this paper attempts to examine and describe the science learning management strategies that have been implemented by teachers in Islamic schools in Lamongan District as a series of research entitled "Strengthening Education of Science in Islamic Schools in Indonesia". 


\section{METHODS}

This research is a qualitative descriptive research that aims to explain the related science learning management strategy in Islamic schools in Lamongan, East Java. The subjects of the study is six Islamic background schools were chosen by purposive sampling. Technique of collecting research data using interviews, observation, and documentation for four months, starting from January to April 2017. In this study, conducted an analysis of the results of data collection on the related science management strategy refers to Reigeluth and Merrill (1979) which consisting of: a) Scheduling the use of strategies, b) Recordkeeping of student learning progress, and c) Motivational management.

Scheduling use strategies are the use of strategies in science learning planned by teachers, both in the classroom and in the science laboratory. Then Recordkeeping of student learning progress is a science teacher in assessing the progress of the learning outcomes of how the assessment process is conducted, including documenting the progress of student learning progress. While Motivational Management is a strategy used by science teachers in improving students' motivation during learning activities. The form is more on what kind of stimulus by science teachers in improving motivation in following the learning process and how students respond to the stimulus.

\section{RESULTS AND DISCUSSION}

Scheduling the Use of Strategies. The duration of science learning at the junior high school level is 5 hours of lessons per week. Some school devide the 5 lessons into two to three times a week. During the learning process of science by the duration, the majority of teachers still use the lecture, assignment and question and answer method in delivering the science subject matter to the students. The use of other learning methods, such as demonstrations, discussions, observations, practicum, and others relevant in science cultivation are rarely used except in uncertain times. Learning activities are also mostly done in the classroom in the form of tutorials in accordance with the material contained in the manual. Practical laboratory activities are rarely performed, in addition to the limited tools and media practices as well because the available space is also less representative. Even from 6 Islamic schools that are the subject of research, one of them does not have a science laboratory.

Table 1. Scheduling Strategy of Science Learning in Laboratory

\begin{tabular}{l|l}
\hline \multicolumn{1}{c|}{ Islamic Schools } & \multicolumn{1}{c}{ Learning Activities Evidence of the Science Process } \\
\hline MTs Putra Putri Lamongan & $\begin{array}{l}\text { Despite having a science laboratory with equipment that is complete } \\
\text { enough, but because the laboratory space is less representative, so } \\
\text { that science learning activities are mostly done in the classroom. } \\
\text { There is no exact scheduling for lab work in the laboratory, teachers } \\
\text { only adjust to the material that is possible with the tools and } \\
\text { materials available can be used for the practice of the science } \\
\text { process. During one semester counted only two times the science } \\
\text { teacher practicum in the lab. Practicum performed is a proof of } \\
\text { heavy type of detergent, milk, and oil substances. }\end{array}$ \\
\hline MTs Maslakul Huda Paciran & $\begin{array}{l}\text { This school has a science laboratory with a large and representative } \\
\text { room, but available lab equipment is limited. Learning science in the } \\
\text { laboratory is also done in turns with students MA Maslakul Huda } \\
\text { who is a complex. During the study, the teacher only once used the } \\
\text { laboratory to prove the scientific process, namely the proof of water } \\
\text { pollution caused by household waste }\end{array}$ \\
\hline SMP Muhammadiyah 1 Babat & $\begin{array}{l}\text { Science learning is done in the classroom, despite having a science } \\
\text { laboratory, but the laboratory has switched functions to class. So in } \\
\text { the process of learning sometimes science teachers often bring } \\
\text { laboratory tools into the classroom. }\end{array}$ \\
\hline SMP Empat Lima Babat & $\begin{array}{l}\text { Does not have a science laboratory, so the whole process of learning } \\
\text { science is done in the classroom. The science practicum equipment } \\
\text { owned by only two microscopes. }\end{array}$ \\
\hline
\end{tabular}




\begin{tabular}{l|l}
\hline $\begin{array}{l}\text { MTs Muhammadiyah 15 } \\
\text { Lamongan }\end{array}$ & $\begin{array}{l}\text { This school has a science laboratory with a limited number of } \\
\text { practicum equipment. The use of props that exist in the laboratory } \\
\text { only if it is in accordance with the material being studied, if in the } \\
\text { laboratory there is no equipment in accordance with the theme, the } \\
\text { teacher usually makes the media simple. }\end{array}$ \\
\hline MTs Miftahul Jinan Deket & $\begin{array}{l}\text { It has a science laboratory, but the space is less suited to the number } \\
\text { of student ratios, so teachers sometimes bring science lab equipment } \\
\text { into the classroom to explain the science process. However, for } \\
\text { certain laboratory equipment that can not be transferred into the } \\
\text { classroom, the teacher still carries out science learning in the } \\
\text { laboratory that adapts to the material being studied. }\end{array}$
\end{tabular}

Schools do not provide standards for science teachers in implementing learning strategies both in the classroom and in the laboratory. The principal only emphasizes the importance of using learning strategies that adapt to the development of science and technology. No specific scheduling is done by science teachers in the use of science learning strategies. However, the use of learning methods in accordance with the material taught. In some schools that are the subject of research, science learning activities are still more dominated by teachers (teacher-centered learning). Students hear more material explanations given by teachers. The teacher's strategy in delivering science materials to the studied school is also not much different from most other schools. Most importantly according to the teacher, all materials are delivered according to the Basic Competence listed in the handbook based on the Curriculum of 2013.

The science learning strategies used by teachers are textually included in each document making the Lesson Plans. The use of the learning strategy follows the concept of the approach set in the 2013 curriculum with Project Based Learning, Discovery Learning and also Problem Based Learning. However, the use of such strategies adapts to the material being taught

However, at certain times that are not scheduled, teachers provide more applicable learning methods that involve students in these learning activities. For example, demonstration methods, and practicum with homemade media, such as measuring the heat of an object using a simple thermometer, although the end result of the practice is not the same as the instructional video tutorial, after review, it turns out the different thermometers are used so the results are different too. The use of discussion method has also been done in science learning, that is when the material about global warming. Students are divided into four groups with each group given Student Worksheet which contains various issues about global warming. Each group is given 30 minutes to discuss the various issues. Once considered sufficient, representatives of each group took turns forward to convey the results of their discussion. Then the other group asked questions and responses from the group's presentation.

Learning strategy using classroom practice method has also been done by science teacher to show the process of eruption of the mountain. The teacher divided the class into groups, with each group given materials and equipment, including sand, trays, soda, glass, etc. Students observe and make identification to be formulated from the observation of the eruption of the eruption of the mountain and how the mountain can erupt. In addition, science teachers to explain the population material using a game called Snowball. The way after the teacher explains the material about the population, then in the remaining time the teacher gives questions about the population material on one student, then if the student can not answer, then the student must stand up and appoint one of his friends to help her answer. If the student who asked for help also can not answer, then the relevant also all of you stand up and appoint another friend and so on. This is done by teachers to know the level of students' understanding of the material that has been studied. Apparently because of the game of the snowball makes almost $80 \%$ of students stand because it can not answer the teacher questions about the material population. In addition, once a meeting, the teacher conducted a science experiment on the form of substance. The teacher's move brings learning materials such as ice cubes, water, candles into the classroom. Then the teacher experiments on the variety of 
changes in the form of substances in front of the

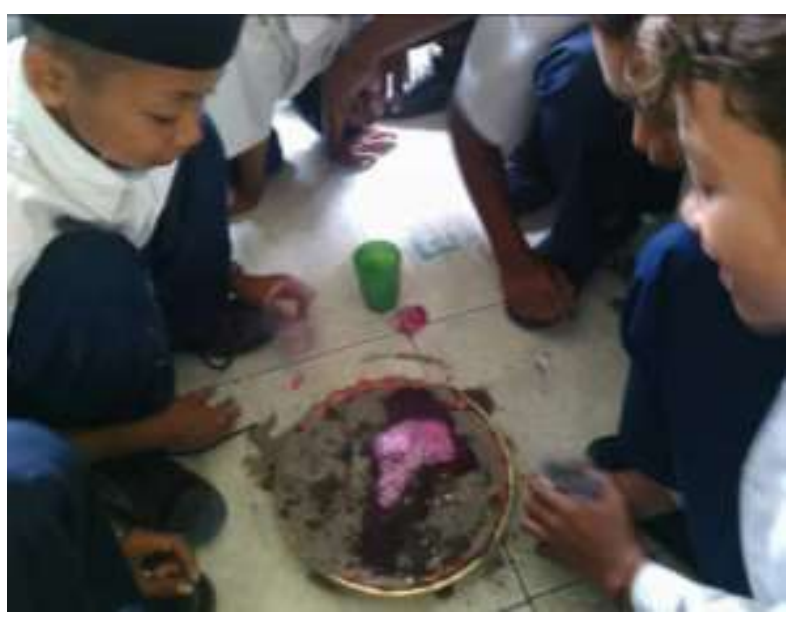

class.

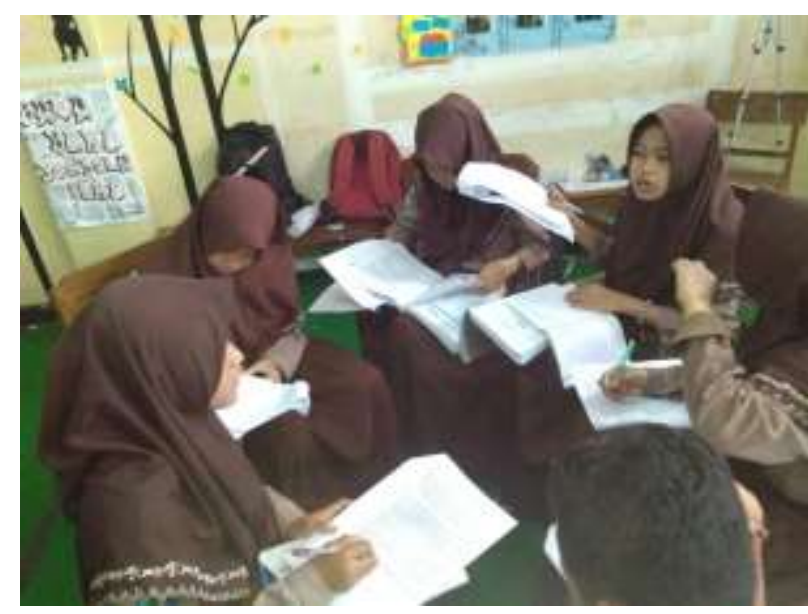

Figure 1. Learning strategies in the form of lab work in class and discussion in science learning process

\section{Recordkeeping of Student Learning} Progress. Formal written assessment is officially given to each student on science learning activities in mid-semester and end of semester in the form of study result cards. The report cards are distributed in the middle and the end of the semester as achievements of accumulated learning outcomes over the duration of the time. In addition, science teachers also keep track of their learning progress through a variety of assessments, but in general by giving daily tests. Student progress is known to subject teachers when students are given assignments. Through the assignment or test daily and weekly or monthly then it is known that students who have not reached mastery in learning. Handling of students who have not achieved mastery learning that is given additional hours and special assistance to catch up with the understanding of the material that has been taught from other students.

In addition to daily tests to determine the level of students' learning knowledge, teachers sometimes also give pretest at the beginning of learning and pretest at the end of science learning. The format of the assessment in this form is not done routinely, but only at certain moments according to the material that according to the science teacher needs to be done pretest and posttest. The teacher also does a recording of student learning progress by giving question and answer relating to the material that has been learned both in the middle and end of learning. This is done to find out directly the level of students' understanding of the science materials that have been studied both orally and in writing.

Specifically, science teachers have not recorded student progress with a special form as a material for teacher evaluation in achieving the delivery of material that has been taught. However, the teacher writes the students' overall learning progress through the teaching journal each time the meeting is held. The teacher evaluates the progress of learning through daily test and also midterm test. From the results of daily tests and also the semester that has been done the teacher, the teacher can know the students who have not reached the Minimum Exhaustiveness Criteria as standardized in the school. Handling for students who have not achieved a minimum mastery in the learning process of science is to provide additional assignment in a structured form of school work or other support activities such as remedial and enrichment.

Motivational Management. Many students perceive science lesson. Avoid using passive voice if is possible as a difficult and monotonous lesson. The paradigm makes many students less enthusiastic to follow science lessons, especially if the science teacher is less able to bring the sound of learning will certainly make the learning climate less comfortable. Moreover, some of the science materials that tend to go on and contain scientific formulas are also perceived by most students to saturate things. This fact becomes a challenge for science teachers in improving their students' learning motivation. 
Motivation is given by science teachers every time they start learning. The verbal form of motivation is the inculcation of character values to the students such as "study hard to be useful child, learn it with spirit". Motivation is also given by the teacher not only when starting the lesson but while the child is not doing school work, the teacher motivates the students to keep performing the task and if it can not be done at home the teacher can provide guidance or can workgroup. Another form of teacher strategy in fostering motivation to learn science to students is given every meeting students who according to teachers considered less attention to the lesson, look moody or lack of spirit. Motivating in the form of moral support by reminding the purpose of learning and also reminded of the efforts of parents in their effort to send their school. Motivation is often done by the teacher orally, although there are some nonverbal apperception displayed by students on the classroom wall to motivate themselves in improving their learning spirits.

In addition, as an Islamic-based school, the majority of teachers integrate Islamic values in Islamic materials. This is an attempt to foster their learning motivation, because learning science also contains Islamic teachings in it. In addition, teachers often provide additional value, rewards, and praise to students who are active during the learning process. Another strategy is that teachers typically use animated videos obtained from downloads on you tube that are related to the material to be apperception. Through the animated video the students are stimulated to be interested in the material they will learn.

\section{CONCLUSION}

Textually teachers write learning strategies that are documented in the Lesson Plans. However, the learning strategy is not scheduled by science teachers. The majority of teachers still use lecture, question and answer methods and assignments during the learning process of science. Sometimes people use demonstration methods, games, and experiments. Science learning activities are mostly done in the classroom, this is because the school does not have a representative laboratory for practical use. So that science learning conducted by students tend to be abstract through the tutorial material presented by the teacher.

No form that specifically records the development of students' science skills. The recording of students' scientific progress is done through daily test, pretest and posttest, question and answer, midterm exam and final exam of semester. For students whose ability and science value is less than the minimum completeness criterion that becomes the school standard, the student is given additional and remedial tasks as a form of material enrichment. Teachers have a variety of strategies to foster the motivation to learn science that is considered by most students difficult and boring. Among them is by giving gifts, additional values and praise. In addition, teachers sometimes integrate Islamic values in science materials and also use animated video to serve as apperception. The rest give more oral motivation in the form of giving advice and words of motivation.

\section{ACKNOWLEDGMENTS}

Acknowledgments were conveyed to the Indonesian Consortium for Religious Studies on a research program entitled "The Strengthening of Science Education in Islamic Schools in Indonesia". Further thanks to the United States Agency for International Development (USAID) and National Academy of Sciences (NAS) for supporting the research program.

\section{REFERENCES}

Baswedan, A. R. (2004). Political Islam in Indonesia: Present and Future Trajectory. Asian Survey, September/October 2004, Volume 44, pp. 669-690.

Effendy, B. (1994). Islam and the State: The Transformation of Islamic Political Ideas and Practices in Indonesia. Ohio: The Ohio State University.

Gade, A. M. (1999). An Envy of Goodness: Learning to Recite the Qur'an in Modern Indonesia. Chicago, Illinois : The University of Chicago.

GOK, T. \& Silay, I. (2008). Effects of Problem Solving Strategies Teaching on The Problem Solving Attitudes of Cooperative Learning Group in Physics Education. 
Journal of Theory and Practice in education. 4 (2):253-266

Hefner, R. W. (2000). Civil Islam: Muslims and Democratization in Indonesia. Princeton: Princeton University Press.

Heryanto, A. (2015). Identitas dan Kenikmatan: Politik Budaya Layar Indonesia. Jakarta: Kepustakaan Populer Gramedia.

Jones, C. (2010). Images of Desire: Creating Virtue and Value in an Indonesian Islamic Lifestyle Magazine. Journal of Middle East Women's Studies, 6 (Marketing Muslim Woman), pp. 91-117.

Liliasari. (2009). Tantangan Pembelajaran Sains di Abad ke-21 dan Kiat-Kiat Penanggulangannya. Seminar Nasional Pendidikan IPA Asosiasi Guru Sains Indonesia (AGSI) ke-V, Bandung

Milan, R. (2007). Pengelolaan Kelas Model Pakem. Jakarta : Dirjen PMPTK

OECD. (2005). First Result from PISA 2003.

Paris : OECD publishing

OECD. (2007). PISA 2006 Science

Competencies for Tomorrow's World Vol

1: Analysis. Paris: OECD publishing.

OECD. (2010). PISA 2009 Result: What

Students Know and Can Do-Student

Performance in Reading, Mathematics and Science, Vol I. Paris : OECD publishing.

OECD. (2012). PISA 2012 Result: What

Students Know and Can Do-Student
Performance in Reading, Mathematics and Science, Vol I. Paris : OECD publishing.

OECD. (2016). PISA 2015 Result: Assessment and Analytical Framework-Science,

Reading, Mathematic and Financial

Literacy. Paris : OECD publishing.

Rahmawati. (2016). Hasil TIMSS 2015 [handout powerpoint slides]. Puspendik: Kementrian Pendidikan dan Kebudayaan RI.

Reigeluth, C.M. \& Merril, M.D. (1979). Classes of Instructional Variables. Educational Technology.

Rudnyckyj, D. (2009). Market Islam in Indonesia. The Journal of the Royal Anthropological Institute, Vol. 15, Islam, Politics, Anthropology (2009), pp. S183S201, 15(Islam,Politics, Anthropology), pp. S183-S201.

Sanjaya, W. (2011). Pembelajaran dalam Implementasi Kurikulum Berbasis Kompetensi. Jakarta: Kencana.

Smith-Hefner, N. J. (2007). Javanese Women and the Veil in Post-Soeharto Indonesia. The Journal of Asian Studies, May, Volume 66, pp. 389-420

Susanto, A. 2(013). Teori Belajar dan Pembelajaran di Sekolah Dasar. Jakarta: Kencana.

Wisudawati, A.W. \& Sulistyowati, E. (2014). Metodologi Pembelajaran IPA. Jakarta: Bumi Aksara. 